\title{
A Technical Experiment on Biogas Production from Small-Scale Dairy Farm
}

\author{
Ahmad Al-Rousan', Anas Zyadin 2* \\ ${ }^{1}$ School of Forest Sciences, University of Eastern Finland, Joensuu, Finland \\ ${ }^{2}$ National Energy Research Center, Amman, Jordan \\ Email: a.rousan@nerc.gov.jo, ${ }^{*}$ anas.zyadin@gmail.com
}

Received 16 December 2013; revised 15 January 2014; accepted 13 February 2014

Copyright (C) 2014 by authors and Scientific Research Publishing Inc.

This work is licensed under the Creative Commons Attribution International License (CC BY). http://creativecommons.org/licenses/by/4.0/

(c) (i) Open Access

\section{Abstract}

The key objective of this study was to evaluate the economic feasibility of producing biogas from privately-owned dairy farm in the North of Jordan. This experiment did not adopt Best-AvailableTechnology (BAT) but rather traditional unit manufactured with minimized costs through installing locally produced materials to avoid economic burden on the farmers' production costs. A thermophilic biodigester unit was built sub-surface with $22 \mathrm{~m}^{3}$ capacity $\left(15 \mathrm{~m}^{3}\right.$ manure tank plus $7 \mathrm{~m}^{3}$ biogas holder) in a relatively small scale dairy farm. The daily feed was about 500 liter of cow slurry (150 - 200 liter cow manure) and the remaining were production liquids. The retention time was approximately 25 - 30 days and the seasonal temperature measured was about $18^{\circ} \mathrm{C}$ $20^{\circ} \mathrm{C}$. The unit was thermally insulated; therefore, the temperature fluctuation was slightly around $+/-3^{\circ} \mathrm{C}$. The daily biogas production was estimated at $7 \mathrm{~m}^{3}$ equivalent to $4 \mathrm{~kg}$ of Liquefied Petroleum Gas (LPG) or $11(12.5 \mathrm{~kg})$ LPG cylinders per month worth US\$140. The methane percentage was $60 \%$ in relatively warm temperature $\left(18^{\circ} \mathrm{C}-20^{\circ} \mathrm{C}\right)$ and approximately $56 \%$ in colder temperatures. Other benefits of this experiment involve in-farm waste management and disposal, compost as a bio-fertilizer, and emissions savings of approximately 32 tons of $\mathrm{CO}_{2}$ equivalent/year. This experiment demonstrates the economic feasibility of replicating the biogas unit to larger cow farms giving the high prices of fossils fuels and possible inclusion to the CDM clean projects for emission certificates. A hybrid system of biogas unit connected to Solar Water Heater (SWH) to maintain suitable temperatures for biogas production in colder seasons is worth considering and testing. Governmental institutions are strongly recommended to issue and ratify new bioenergy directives and policies that provide starter loans and guarantee the purchase of the biogas-based electricity from large scale farms.

\section{Keywords}

Anaerobic Digestion; Biogas; Cow Manure; Jordan

\footnotetext{
${ }^{*}$ Corresponding author.
} 


\section{Introduction}

Due to the steadily increasing earth population and the unfettered expansion of industrial and agricultural activities worldwide, the demand for primary energy is unequivocally escalating [1] and proportionately juxtaposed to increasing bio-wastes production from human consumption and by-products of economic and agricultural activities. On the other hand, the staggering high prices of fossil fuels accompanied by perplexing geopolitical conflicts threaten the economic and political stability of many oil-poor countries and threaten the livelihoods of vulnerable poor people. To that end, the endeavor toward utilizing local bio-wastes resources, particularly from otherwise landfilled biowastes resources, is fundamental to considerably reduce dependence on fossil fuels, boost economy, and a strategy to revitalize rural communities [2] [3].

Biowastes encompass agricultural and forestry residues, municipal solid and liquid wastes, human food wastes, and considerable quantities of manure excreted by ruminant animals [4]. Regarding animal manure, the world's livestock population is increasing especially in China and India; therefore, the manure-based methane emissions are projected to increase by $16 \%$ by 2030 in almost all continents and contribute about 240 million metric tons of carbon dioxide equivalents of methane emissions [4]. In the Arab countries, the livestock population is estimated at 347 million, which accounts to approximately $7 \%$ of the world's livestock population [5]. Furthermore, In the Arab Gulf States, waste generation predicted to increase from 22 million tons in 2010 to 29.07 million tons in 2017. Consequently, the Arab governments are urgently looking for innovative solutions to the critical issues around sustainable waste management. In this context, utilizing and fermenting the almostfree-to-take biowastes from small to large scale dairy cow farms is a win-win approach: it is economically attractive through valorization of wastes and providing part of the daily energy needs and environmentally friendly through reducing the harmful methane emissions and avoiding public health risks from the accumulation of wastes nearby residential areas [2] [4] [6].

To avoid any economic burden of installing expensive high-tech biogas units, farmers could be assisted to build traditional mini-unit using local construction materials and according to quantities of daily manure produced from their farms. Bacterial/Anaerobic digestion of animal manure has been globally developed to produce considerable quantities of bio-methane (a natural gas alternative), which can be directly combusted to generate electricity or heat and also in transportation sector. Around the globe, manure-based biogas production facilities are being developed assiduously. Over 173 thousand biogas plants are operating in Nepal [7] and biogas plants in China are estimated to have reached 43 million by 2011 [4]. In Germany, and according to the German Biogas Association, about 1000 biogas plants are being constructed annually, corresponding to about $300 \mathrm{MW}_{\mathrm{el}}$ [8]. In Africa, the Kenya Domestic Biogas Implementation Programme (KENDBIP) started in 2010 disseminating domestic biogas digesters to Kenyan cattle and pork farmers [9]. Within a few months the programme has installed 10,000 bio-digesters, providing the farmers with biogas for cooking and lighting and bioslurry (a potent organic fertilizer) for their agricultural activities [10]. It is also worth mentioning that large-scale biogas plants being developed and now operating with the largest being in the Netherlands, Denmark, and Spain [4]. The aforementioned initiatives illustrate that community-based initiatives accompanied by vigilant policies and economic incentives are key strategic approach, and that utilizing the local bio-wastes does not require high upfront investments.

In Jordan, substantial quantities of biowastes from various sectors exists however largely underutilized [2]. Further assessments of biowastes were conducted to scrutinize the economic feasibility of biogas production ${ }^{1}$ [11]. The study reported that about 1.22 million $\mathrm{m}^{3}$ biogas or 662 thousand $\mathrm{m}^{3}$ methane can be produced per day. This is equivalent to 242 million $\mathrm{m}^{3}$ natural gas per year with total potential power generation would amount to $275 \mathrm{MW}_{\text {th }}$ or $96.4 \mathrm{MW}_{\mathrm{el}}$ [11]. In Jordan, so far, only two large-scale biogas projects were developed: the Jordan Biogas Company [12] that simply harvests biogas from abandoned landfill in combination with other biogas unit that utilizes the municipal wastes from slaughter houses, central vegetable and fruits market, and liquid by products of yeast, dairy, and animal feed factories. The total power capacity of the biogas company is currently 3.5 $\mathrm{MW}_{\mathrm{h}}$. The second project being developed is the Al-Assamra Biogas Station, which produces biogas from fermenting the primary and secondary sludge after being thickened, mixed and pumped into four $15,000 \mathrm{~m}^{3} \mathrm{ca}-$ pacity anaerobic sludge digestion unit to produce approximately $50,000-60,000 \mathrm{Nm}^{3} /$ day of biogas with total power generation capacity from the biogas generators, inlet and outlet turbines is $8.725 \mathrm{MW}$ [13].

Nonetheless, there is a considerable potential for producing biogas from municipal solid wastes, olive cake, ${ }^{1}$ The report is available from the authors upon request. 
sludge, and animal manure especially from dairy cow and poultry manure [2] [14]. Besides the lack of explicit legislations and economic incentives to utilize such resources, poor knowledge and awareness among farmers is one key obstacle to develop biogas industry in Jordan. In summer time, farmers in Jordan valley cheaply purchase fresh poultry and cow manure to fertilize and prepare their lands for winter farming. Such activity is environmentally unfriendly; it releases methane emissions and produces unpleasant odor to neighboring residential areas, encouraging dangerous insects' aggregations, and threatening surface and groundwater bodies. Jordan is highly dependent on imported fossil fuel energy; around $96 \%$ of the energy needs are imported in forms of crude oil and natural gas [15]. Additionally, and due to high influxes of refugees, Jordan is experiencing unprecedented growth of energy demand-approximately 7\% annually and 500 MW electricity demand growth annually. Furthermore, a price increase of US $\$ 1$ per barrel of oil will accounts for additional economic burden of US\$50 million on the Jordan's economy annually.

In order to decrease the Kingdom's dependency on internationally oscillating fuel prices, to enhance security of supply and to shift the patterns of energy supply and demand towards a sustainable direction, the Government of Jordan, in its 2007 Energy Strategy, has set ambitious goals for the development of renewable energies and energy efficiency. By the year 2020, the share of renewable energies in primary energy supply is to increase from $1 \%$ to $10 \%$ [16]. A number of single targets have been set, such as for wind power (installation of $600 \mathrm{MW}$ ) and solar thermal energy (300 - 600 MW) [16]. Biogas has also been identified as a potential source of energy to contribute to the 2020 energy target. In fact, the government lately decided to abolish the fossil fuel and electricity subsides, consequently, the price of one $12.5 \mathrm{~kg}$ Liquefied Petroleum Gas (LPG) cylinder jumped from (6, 5 JD) or US\$9 up to (10 JD) or US\$14. Such economic reform guarantees biogas production as a competitive approach especially for small-scale farmers who largely depend on LPG cylinders for space-heating and cooking in their farms.

\section{The Anaerobic Digestion (AD) and Technical Considerations in Biogas Plants Assembly}

Anaerobic digestion is a biochemical process in which particular strains of bacteria digest biomass in an oxygen-free environment under suitable temperature and humidity environments [4] [6]. The fermentation process leads to the breakdown of complex biodegradable organics in a three-phase process: Hydrolysis, Acidogenesis, and Methanogenesis [17]-[23] (see Figure 1). In Hydrolysis phase, exoenzymes (hydrolase) bacteria decompose-complex organic molecules (fats, cellulose, starch,) in waste into simple sugars, amino acids, and fatty acids. During Acidogensis phase, shorter carbon chains of volatile fatty acids (lactic, propionic, and valeric acids) are created by acidogenic bacteria, which are then digested by acetogenic (homoacetogenic) microorganisms to produce acetic acid, carbon dioxide, and hydrogen. In the final phase, Methanogenesis, the methanogenic bacteria produce methane (biogas) from acetic acid, hydrogen and carbon dioxide, which typically contains $40 \%$ - 60\% methane and 30\% - 40\% carbon dioxide.

Maintaining optimal temperature for the anaerobic digestion process is a quintessential aspect because varying temperatures affect the overall rate of digestion process, the hydraulic retention time, and the composition of the methanogenic bacteria. Research studies have shown that anaerobic digestion can be maintained at psychrophilic $\left(12^{\circ} \mathrm{C}-16^{\circ} \mathrm{C}\right.$ such in landfills), or mesophilic $\left(35^{\circ} \mathrm{C}-37^{\circ} \mathrm{C}\right.$ such in animal rumen), or thermophilic environment $\left(55^{\circ} \mathrm{C}-60^{\circ} \mathrm{C}\right.$ such in artificially made biodigester). In thermophilic conditions, the optimal temperature for maximum biogas production from animal manure was $39^{\circ} \mathrm{C}-43^{\circ} \mathrm{C}$ [20]. Table 1 summarizes the optimal conditions for AD process.

Another important element in anaerobic digestion process is the amount of carbon and nitrogen present in the organic materials, which is represented by the carbon to nitrogen (C:N) ratio [24]. Unlike, for example, the lignocellulosic crop residues with low nitrogen content and high C:N ratio ranging from 60 to 90 , animal manure has a low C:N ratio ranging from 10 - 20 (20 for cow manure) [4] [6] [17] [21]. A high C:N ratio is an indication of rapid consumption of nitrogen by methanogens and results in lower biogas production (Table 2). The optimal range of C:N ratio for anaerobic digestion is reported to be in the range of 25 to 35 [25]. See Table 2 for a comparison between selected livestock manure.

Biogas produced from anaerobic digestion typically consists of a mixture of methane $55 \%-70 \%\left(\mathrm{CH}_{4}\right), 30 \%$ $45 \%$ carbon dioxide $\left(\mathrm{CO}_{2}\right)$, and traces $(0 \%-2 \%)$ of ammonia and approximately $500 \mathrm{ppm}$ hydrogen sulfide $\left(\mathrm{H}_{2} \mathrm{~S}\right)$ [4] [6] [20] [23]. The energy content of methane gas that is produced from manure is around $4800-6700$ 


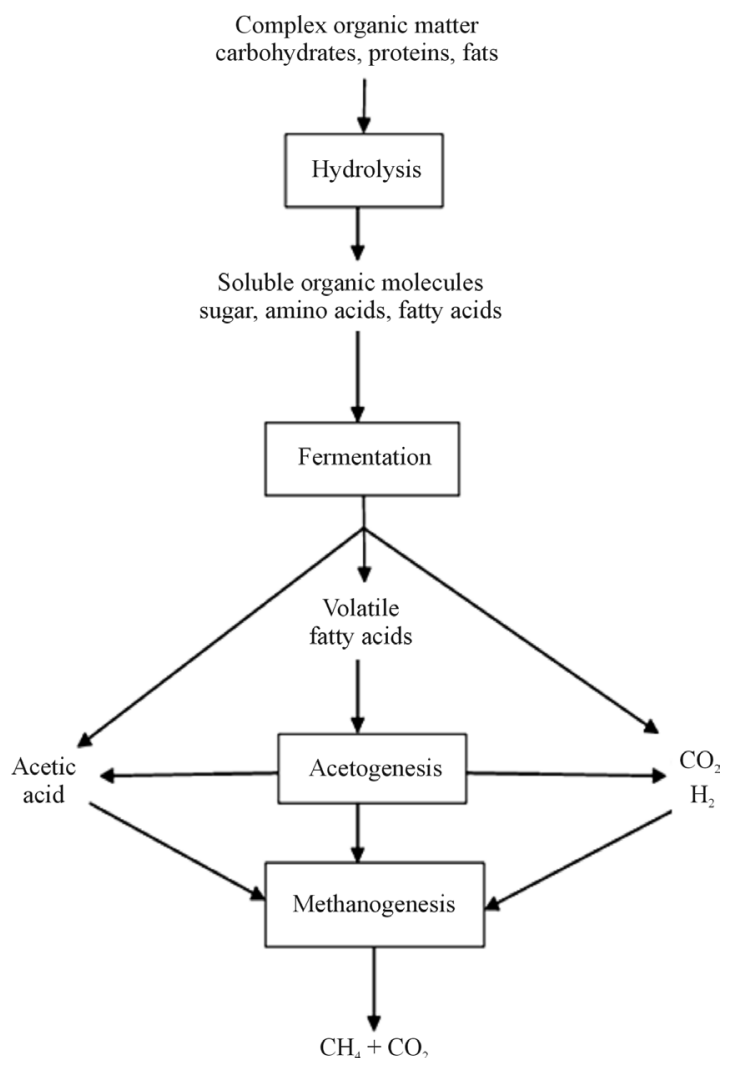

Figure 1. Flow chart of anaerobic digestion process [18].

Table 1. Suitable conditions for anaerobic digestion [4].

\begin{tabular}{ccc}
\hline Parameter & Hydrolysis/acidogenesis & Methane synthesis \\
\hline Temperature & $25^{\circ} \mathrm{C}-35^{\circ} \mathrm{C}$ & Mesophilic $32^{\circ} \mathrm{C}-42^{\circ} \mathrm{C}$ Thermophilic $50^{\circ} \mathrm{C}-58^{\circ} \mathrm{C}$ \\
$\mathrm{pH}$ value & $5.2-6.3$ & $6.7-7.5$ \\
C:N ration & $10-45$ & $20-30$ \\
Dry matter content & $<40 \% \mathrm{DM}$ & $<30 \% \mathrm{DM}$ \\
required C:N:P:S ratio & $500: 15: 5: 3$ & $600: 15: 5: 3$ \\
Trace elements & No requirements & Essential: $\mathrm{Fe}, \mathrm{Mn}, \mathrm{Zn}, \mathrm{Cu}, \mathrm{Ni}, \mathrm{Co}, \mathrm{Mo}, \mathrm{Se}$ \\
\hline
\end{tabular}

Table 2. Biogas potential from selected livestock manure [4].

\begin{tabular}{|c|c|c|c|c|c|}
\hline Animal & $\begin{array}{l}\text { Total manure } \\
\text { (kg/head/day) }\end{array}$ & $\begin{array}{l}\text { Total solid (TS) } \\
\text { (kg/head/day) }\end{array}$ & $\begin{array}{c}\text { Biogas yield } \\
\left(\mathrm{m}^{3} / \mathrm{kg} \text { dry matter) }\right.\end{array}$ & $\begin{array}{l}\text { Carbon/Nitrogen } \\
\text { ratio }(\mathrm{C} / \mathrm{N})\end{array}$ & $\begin{array}{c}\text { Volatile solids (VS) \% } \\
\text { fresh manure }\end{array}$ \\
\hline Cow & 20 & 4.0 & $0.20-0.50$ & $18-25$ & 13 \\
\hline Buffalo & 25 & 4.5 & $0.15-0.32$ & $18-25$ & - \\
\hline Pigs & $1-5$ & 0.6 & $0.56-0.65$ & 13 & 12 \\
\hline Sheep & 1.8 & 0.6 & $0.37-0.61$ & 29 & - \\
\hline Poultry & 0.1 & 0.03 & $0.31-0.54$ & - & 17 \\
\hline Horses & 24 & 7.1 & $0.20-0.30$ & $24-25$ & - \\
\hline Rabbits & 0.2 & 0.1 & 0.36 & - & - \\
\hline
\end{tabular}


$\mathrm{kcal} / \mathrm{m}^{3}$ compared with pure methane gas, which contains energy of $8900 \mathrm{kcal} / \mathrm{m}^{3}$ [23]. When combusted, a clear blue flame is an indication of high quality biogas. Cow manure has been selected for investigation in this study because only small-to-large scale dairy farms exist in Jordan, thus, the quantities of cow manure produced daily deemed sufficient to install a biogas unit. Furthermore, the hot arid climate of Jordan provides optimal temperatures for the anaerobic digestion. In experimental study by Aoki et al. [26] a $60 \mathrm{~m}^{3}$ capacity digester operating with dairy manure at a digester temperature of $55^{\circ} \mathrm{C}$, average loading rate of about $7 \mathrm{~kg} / \mathrm{m}^{3} /$ day and hydraulic retention time of 13 days, the average biogas production was $150 \mathrm{~m}^{3} /$ day with $56 \%$ methane content in a cold region in Japan.

The objective of this technical experiment is mainly to construct a mini-unit for biogas production in a dairy cow farm to improve waste management and produce biogas for heat generation. The project also aims at assessing the economic feasibility of biogas production in small scale farms to generate a production template to possibly replicate the biogas production facility to other areas in Jordan.

\section{Experiment Location}

The project demonstration site is located in highly populated dairy cow farms areas like Al-Khaldieh district in Al-Mafraq Governorate. This region houses approximately 50\% of total dairy farms in Jordan. The potential organic waste produced by these dairy farms is estimated at 600 tons per day. Major part of the manure is disposed in landfills or neighboring areas with no considerations to the environment or public health. Random disposal of organic manure is due to the fact that farmers cannot afford the transportation costs to landfills. When installing the biodigester, several aspects and criteria's were taken into account:

1) Applicability: the biodigester is simple in principle and construction, which is easy and cheap to install and operate. The digester is locally fabricated, utilizing the available materials and equipment in the local market.

2) Replicability: successfully installed and operating Biogas Digestion Unit (BDU) will provide possible replication in other farms. The drivers for replication are the cost effectiveness and performance of the mini-biodigester.

3) Marketability: the BDU may create small business at the beginning, which would encourage private corporations to establish a start-up company responsible for installation and maintenance of biogas units.

4) Affordability: optimizing the installation costs of the BDU by using local resources and cutting unnecessary costs. For example, installing underground digester has eliminated the use of feeding pump and eliminating the use of heating coil inside the digester. Instead, hot water discharges out of milking machines were utilized to feed the digester to provide heat to the digester, reusing the milky water in manure mixing before feeding the digester, thus reducing the water resources required for the mixing process and, most importantly, the milky water contains fats and proteins, which enhances biogas production. A reasonable price was achieved so that the farmer is encouraged to install BDU.

5) Reliability: avoid any leakage from the underground digester and steady production of biogas on daily basis.

6) Feasibility (technical and economic): minimizing pumping requirements by using gravity-fed underground digester. Manual mixing of organic wastes before feeding to the digester for few minutes to maintain homogenous substrate and breaking down large particles to avoid inlet pipe blockage. The digester is insulated by $3 \mathrm{~cm}$ of locally produced rock wool (zeolite). The manure is mixed with water by ratio of $1: 2$ to maintain $12 \%$ Total Dry Solids (TDS) content. A stirring is installed inside digester to mix the substrate utilizing the effect of regular daily feeding. The size of the digester is calculated based on the number of cows in the farm and the amount of manure produced by each cow (estimated at $10 \mathrm{~kg}$ per day).

Size of Digester $\left(\mathrm{m}^{3}\right)=$ No. of cows $\times 10$ (liter/day) $* 30$ days $\times 2$

For example a dairy farm has 10 cows, and then the digester size would be:

Manure holder size $=10 \times 10 \times 30 \times 2=6 \mathrm{~m}^{3}$, add $10 \%=\mathbf{6 . 6} \mathbf{~ m}^{3}$

Biogas holder size $=\left(100 \mathrm{~kg} / \mathrm{day} \times 25 \mathrm{~m}^{3}\right.$ biogas $\left./ 1000 \mathrm{~kg}\right)=2.5 \mathrm{~m}^{3}$, add $10 \%=\mathbf{2 . 7 5} \mathbf{~ m}^{\mathbf{3}}$

Digester overall size $=6.6+2.75=\mathbf{9 . 3 5} \mathbf{~ m}^{\mathbf{3}}$

The daily manure feeding $=$ No. of cows $\times 10 \mathrm{~kg}$ waste per cow $=100 \mathrm{~kg} /$ day

The water requirement for mixing $=$ organic waste $\times 2=200$ liter/day

Size of mixing tank $=100+200=300$ liter, we used $0.5 \mathrm{~m}^{3}$ size mixing tank.

To simplify, the biodigester size is equal to (number of cows) $\mathrm{m}^{3}$. Chemical analysis was conducted for cow 
manure samples to identify the sample weight, Total Dissolved Solids (TDS) using drier at $105 \mathrm{C}^{\circ}$ for one hour, volatile solids (VS) using oven at $550 \mathrm{C}^{\circ}$ for 24 hours, and finally lab test for biogas generated from weighted mass of manure equipped with stirrer and water heating path for approximately 14 days. Chemical analysis showed that $\mathrm{C}: \mathrm{N}$ ratio in cow manure is 18.

\section{Construction and Installation of the Thermophilic Biogas Digester}

The size of this unit is $22 \mathrm{~m}^{3}$ ( $15 \mathrm{~m}^{3}$ for manure tank and $7 \mathrm{~m}^{3}$ for the gas holder, serving 15-cows farm). The biodigester was constructed with concrete bricks. The bottom was constructed with water-proof concrete slab and reinforced with iron. Thermal insulation was applied using locally manufactured rock wool (zeolite) with 3 cm thickness. See installation steps (1-9) for clarity.
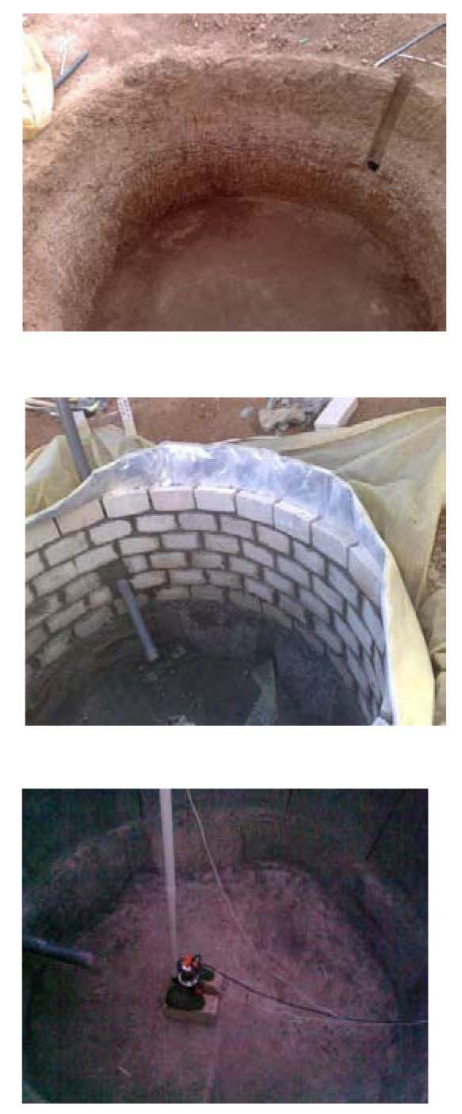
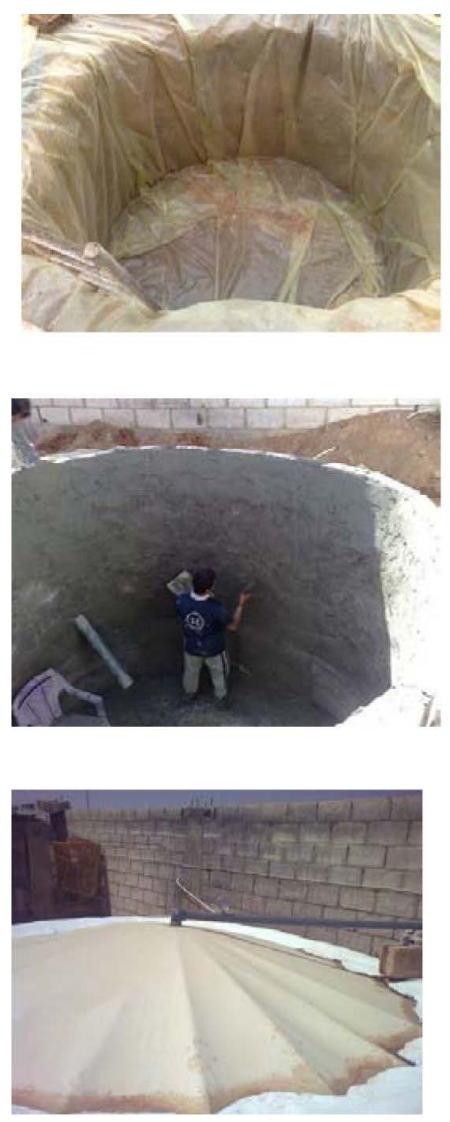

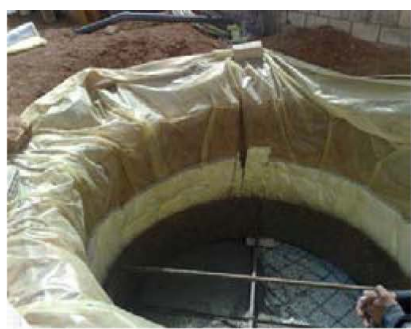

Step 1-3

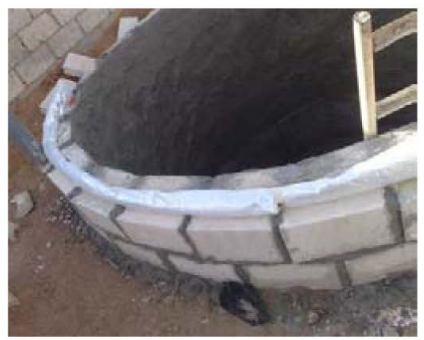

Step 4-6

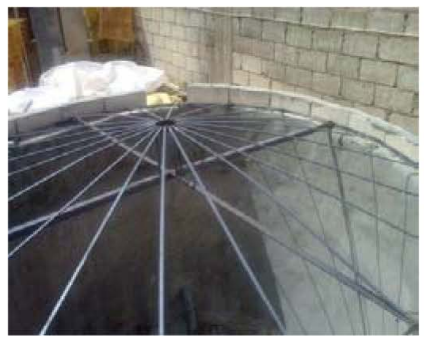

Step 7-9

The installation of this unit involved digging a hole with $3.3 \mathrm{~m}$ diameter and $2.5 \mathrm{~m}$ high (step 1), lining the walls and bottom with PVC sheet to avoid water penetration into digester (step 2), applying thermal insulation for the bottom and the wall, and installing iron grid and pouring the concrete at the bottom slab (step 3). Building the concrete bricks ( $10 \mathrm{~cm}$ wide, $40 \mathrm{~cm}$ long and $20 \mathrm{~cm}$ height) in circular shape and installing the inlet and exit pipes (step 4). The inlet pipe was fixed $40 \mathrm{~cm}$ above the bottom level, while the exit pipe was fixed at $1 \mathrm{~m}$ above the bottom slab; each inclined 45 degrees vertically (step 4). Step 5 involved plastering the bricks with 2 $\mathrm{cm}$ fined concrete. In step 6, the biodigester was raised above the ground level by $1 \mathrm{~m}$, keeping a space for the gas holder; this wall is also insulated with rock wool in double layers of concrete bricks. The next step involved installing circulation pump (immersed sewage pump that equipped with shredder and stainless steel casing, 2 Horse Power (HP), $1 \mathrm{~m}^{3} /$ minute), and installing 2 thermocouples connected to data logging systems (step 7). These apparatuses were installed for sake of measuring the biogas flow. The final steps involved installing the digester cover; a metal frame covered by synthetic leather, fixing the gas holder pipe (2 inches PVC pipe), and finally checking potential biogas leakage by using fiberglass resins (step 8 and 9). The total costs of installing this unit were US\$1472. These calculated costs vary according to labor and raw materials in the region of interest. 


\section{Results and Discussion}

Preliminary results of this technical experiment show that the total amount of biogas produced on daily basis was approximately $7 \mathrm{~m}^{3}\left(210 \mathrm{~m}^{3}\right.$ per month). The percentage of methane gas was $60 \%$ with a density of $1 \mathrm{~kg} / \mathrm{m}^{3}$, which is relatively acceptable and corresponds to previous studies. For a comparison purpose, the (12.5 kg) LPG gas cylinder was used as a reference item to the results of this study. The estimated calorific value of biogas was $33.3 \mathrm{MJ} / \mathrm{kg}$, and for methane $55.5 \mathrm{MJ} / \mathrm{kg}$, while it is estimated about $46.1 \mathrm{MJ} / \mathrm{kg}$ for LPG. Therefore, $1 \mathrm{~kg}$ of biogas is equivalent to $0.72 \mathrm{~kg}$ of LPG and that 1 LPG (12.5 kg) cylinder is equivalent to $18 \mathrm{~m}^{3}$. Based on these assumptions, the experiment was producing $4 \mathrm{~kg}$ of LPG gas per day or approximately 11 LPG cylinders per month. The current end-user price of LPG cylinder is about $10 \mathrm{JDs}$ or US\$14. The total energy bill saving is equivalent to US\$140 per month, which is indeed a very attractive amount of savings for a small scale farmer.

There are other benefits and advantages of this experimental study. For instance, waste management and disposal has been substantially improved at the farm site. The biogas unit utilized all the available slurry and prevented the accumulation of fresh manures at the farm yard. This approach reduces insects' aggregation thus reduces public health risks. Furthermore, calculations show that slightly over one and half ton of methane emissions were saved, which is equivalent to 32 tons of $\mathrm{CO}_{2}$ emissions annually. The digested manure (compost) is an excellent fertilizer containing nitrogen, phosphorus, potassium and other nutrients. It also adds organic matter to the soil, which may improve soil structure, aeration, soil moisture-holding capacity, and water infiltration.

Nitrogen content in any manure varies according to the livestock species; feed ration, amount of litter, bedding or soil included, and amount of urine concentrated in manure. Moisture content is also a major consideration. For example: The moisture content of fresh manure is around $70 \%$ to $85 \%$. The moisture content of airdried manure is around $9 \%$ to $15 \%$. As manure dries, the nutrients not only concentrate on a weight basis, but also on a volume basis due to structural changes (settling) of the manure. Volatilization of urine nitrogen can result in considerable loss of nitrogen, up to $50 \%$ or more of the total nitrogen. Generally, dry manure contains 1.5 to 2.2 cubic meters per ton. Manure is a source of many nutrients including: nitrogen, phosphorus, potassium and many others. However, nitrogen is often the main nutrient of concern for most crops. Potassium deficiency is usually quite localized within a field, and would not be corrected with common rates of manure. However, some improvement might be expected with high rates above 10 tons per acre. The high rates needed to correct a potassium (K) deficiency would supply an excess amount of nitrogen for many crops, and this should be avoided (See Table 3). Some key weaknesses of this study involve the incapability of using electric generators to produce electricity due to the little amount of biogas produced. It was recommended to only use the biogas produced for in-farm use such as cooking and space heating. Due to the simplicity of the biogas unit and the modest amount of biogas produced, it was difficult to account emissions saving through international bodies such as Clean Development Mechanism (CDM) since CER (certified emission reduction) limit is around 15,000 tons of $\mathrm{CO}_{2}$ per year. Therefore, we recommend establishing biogas units in large scale dairy cow farms for the sake of electricity production and utilizing emissions reduction certificates.

Further studies are needed to investigate biogas production in poultry farms, especially in major poultry companies. A demonstration unit will assist in evaluating biogas production with explicit economic analysis. The biogas production and methane content has slightly dropped in cold days due to reduced bacterial population and digestion activity. In this regard, a hybrid system that involves the introduction of simple solar panel e.g.

Table 3. NPK and other chemical test for fresh and digested manure for selected animal substrates.

\begin{tabular}{|c|c|c|c|c|c|c|c|}
\hline & Nitrogen & Phosphorus & Potassium & Calcium & Magnesium & Organic matter & Moisture content \\
\hline & $(\mathrm{N})$ & $\left(\mathrm{P}_{2} \mathrm{O}_{5}\right)$ & $\left(\mathrm{K}_{2} \mathrm{O}\right)$ & (Ca) & (Mg) & & \\
\hline FRESH MANURE & $\%$ & $\%$ & $\%$ & $\%$ & $\%$ & $\%$ & $\%$ \\
\hline Cattle & 0.5 & 0.3 & 0.5 & 0.3 & 0.1 & 16.7 & 81.3 \\
\hline Poultry & 0.9 & 0.5 & 0.8 & 0.4 & 02 & 30.7 & 64.8 \\
\hline DIGESTED MANURE & $\%$ & $\%$ & $\%$ & $\%$ & $\%$ & $\%$ & $\%$ \\
\hline Cattle & 2.0 & 1.5 & 2.2 & 2.9 & 0.7 & 69.9 & 7.9 \\
\hline Poultry & 4.5 & 2.7 & 1.4 & 2.9 & 0.6 & 58.6 & 9.2 \\
\hline
\end{tabular}


Solar Water Heater (SWH) with thermal pipes that runs through the course of fresh manure would elevate the manure temperature during cold days and maintain active anaerobic digestion process. In the vein of policymaking and economic incentives, the authors strongly recommend the authorities in Jordan especially Ministry of Agriculture, Ministry of Environment and in collaboration with the Ministry of Energy and Natural Resources to issue new bioenergy directive that provide fiscal support to small and large scale dairy and poultry farmers and producers to encourage the installation of biogas unit at their farms. Such approach however requires outreach and training workshops for farmers to first get acquainted with the biogas concept and benefits. In large scale biogas projects, the introduction of feed-in-tariffs that pledge the National Electricity Company to buy the biogas-based electricity through long term contracts and fixed prices would encourage sector-wide biogas production in Jordan and from various biowastes sources.

\section{Conclusion}

Harnessing biowastes from all sources is undoubtedly necessary to address sustainable wastes management and also a strategic approach to decrease dependence on expensive fossils fuels. Biowastes are projected to increase steadily worldwide. Therefore, deploying biogas production facilities is a win-win economic endeavor. In this study, albeit modest, the biogas produced will assist the famer to cover the monthly heating costs of his farm. Outreach and training workshops for famers would elevate their awareness of biogas production concept, thus, encourages them to adopt such relatively easy-to-adopt technology or facility. A replicate of this experiment would be of valuable economic benefits at the national level. An institutional and policy planning is required at all levels to adopt bioenergy as a key aspect in energy and climate governance and sustainability planning. A hybrid system of solar panels, thermal control unit, heat exchange unit, electric generator, and biodigester is worth testing to ensure maximum biogas, heat and power production.

\section{Acknowledgements}

The authors wish to sincerely thank the USAID/SABEQ program for funding the project, and would like to thank all the technical team who participated in building the project. The owner of the dairy cow farm is also thanked for this cooperation to install the biogas unit in his farm.

\section{References}

[1] International Energy Agency (2010) Word Energy Outlook 2010. International Energy Agency, Paris. www.ieg.org

[2] Al-Rousan, A., Zyadin, A., Azzam, S. and Hiary, M. (2013) Prospects of Synthetic Biodiesel Production from Various Biowastes in Jordan. Journal of Sustainable Bioenergy Systems, 3, 217-223. http://dx.doi.org/10.4236/jsbs.2013.33030

[3] Hoque, M.E. and Gee, L. P. (2013) Biodiesel from Plant Resources—Sustainable Solution to Ever Increasing Fuel Oil Demands. Journal of Sustainable Bioenergy Systems, 3, 163-170. http://dx.doi.org/10.4236/jsbs.2013.33023

[4] Tauseef, S.M., Premalatha, M., Abbasi, T. and Abbasi, S.A. (2013) Methane Capture from Livestock Manure. Journal of Environmental Management, 117, 187-207. http://dx.doi.org/10.1016/j.jenvman.2012.12.022

[5] Al-Jazeera Network (2013) High Prices of Livestock in Arab Countries. People and Economy Documentary. www.aljazeera.net

[6] Demirbas, M.F., Balat, M. and Balat, H. (2011) Biowastes-to-Biofuels. Energy Conversion and Management, 52, 1815-1828. http://dx.doi.org/10.1016/j.enconman.2010.10.041

[7] Gautam, R., Baral, S. and Herat, S. (2009) Biogas as a Sustainable Energy Source in Nepal: Present Status and Future Challenges. Renewable and Sustainable Energy Reviews, 13, 248-252. http://dx.doi.org/10.1016/j.rser.2007.07.006

[8] German Biogas Association. http://www.biogas.org/edcom/webfvb.nsf/id/DE_Homepage

[9] The International Fund for Agricultural Development (2012) Livestock and Renewable Energy. Livestock Thematic Papers. http://www.ifad.org/lrkm/factsheet/energy.pdf

[10] The African Biogas Partnership Programme (2013). http://africabiogas.org/

[11] Azzam, S., Tentcher, W., Kaupp, A. and Broege, M. (2011) Euro-Mediterranean Energy Market Integration Project, Assessment of Feasibility and Biogas Roadmap 2020 for Development of Biogas in Jordan. Support for the Enhanced Integration and Improved Security of the Euro-Mediterranean Energy Market (MED-EMIP).

[12] The Jordan Biogas Company (2013). http://www.jordanbiogas.com/

[13] Word Bank Group (2013) Environmental and Social Review Summary, AS Samra Wastewater Treatment Expansion 
Project. Multilateral Investment Guarantee Agency.

[14] Kablan, M.M. and Alkhamis, T.M. (1999) An Experimental Study for a Combined System of Tar Sand, Oil Shale, and Olive Cake as a Potential Energy Source in Jordan. Biomass and Bioenergy, 17, 507-515. http://dx.doi.org/10.1016/S0961-9534(99)00027-6

[15] Hrayshat, E. (2007) Analysis of Renewable Energy Situation in Jordan. Renewable and Sustainable Energy Reviews, 8, 1873-1887. http://dx.doi.org/10.1016/j.rser.2006.01.003

[16] Ministry of Energy and Natural Resources (2013) Strategic Planning, the 2007 Energy Strategy. Ministry of Energy and Natural Resources, Amman. www.memr.gov.jo

[17] Abbasi, T. and Abbasi, S.A. (2012) Is the Use of Renewable Energy Sources an Answer to the Problems of Global Warming and Pollution? Critical Reviews in Environmental Science and Technology, 42, 99-154. http://dx.doi.org/10.1080/10643389.2010.498754

[18] Zheng, Y., Pan, Z., Zhang, R., El-Mashad, H.M., Pan, J. and Jenkins, B.M. (2009) Anaerobic Digestion of Saline Creeping Wild Ryegrass for Biogas Production and Pretreatment of Particleboard Material. Bioresource Technology, 100, 1582-1588. http://dx.doi.org/10.1016/j.biortech.2008.08.048

[19] Rosenzweig, A. and Ragsdale, S.W. (2011) Methods in Methane Metabolism. Methanogenesis. Elsevier/Academic Press, Oxford.

[20] Feilden, N.E.H. (1981) A Note on the Temperature for Maximum Net Gas Production in an Anaerobic Digester System. Agricultural Wastes, 3, 75-79. http://dx.doi.org/10.1016/0141-4607(81)90008-1

[21] Santosh, Y., Sreekrishnan, T.R., Kohli, S. and Rana, V. (2004) Enhancement of Biogas Production from Solid Substrates Using Different Techniques-A Review. Bioresource Technology, 95, 1-10. http://dx.doi.org/10.1016/j.biortech.2004.02.010

[22] Monnet, F. (2003) An Introduction to Anaerobic Digestion of Organic Wastes. A Report by Remade Scotland. http://www.biogasmax.co.uk/media/introanaerobicdigestion_073323000_1011_24042007.pdf

[23] Rasi, S., Veijanen, A. and Rintala, J. (2007) Trace Compounds of Biogas from Different Biogas Production Plants. Energy, 32, 1375-1380. http://dx.doi.org/10.1016/j.energy.2006.10.018

[24] Verma, S. (2002) Anaerobic Digestion of Biodegradable Organics in Municipal Solid Wastes. Master’s Thesis, Applied Science Columbia University, New York.

[25] Hills, D.J. and Roberts, D.W. (1981) Anaerobic Digestion of Dairy Manure and Field Crop Residues. Agricultural Wastes, 3, 179-189. http://dx.doi.org/10.1016/0141-4607(81)90026-3

[26] Aoki, K., Umetsu, K., Nishizaki, K., Takahashi, J., Kishimoto, T., Tani, M., et al. (2006) Thermophilic Biogas Plant for Dairy Manure Treatment as Combined Power and Heat System in Cold Regions. International Congress Series, 1293, 238-241. http://dx.doi.org/10.1016/j.ics.2006.03.014 